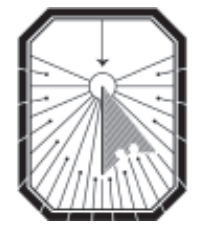

KYIV-MOHYLA

HUMANITIES JOURNAL

KYIV-MOHYLA SCHOLARLY PEER-REVIEWED JOURNALS

Playing Upon Biographical Myths: William

Shakespeare and Lesia Ukrainka as Characters in Contemporary Drama

Author(s): Natalia Vysotska

Source: Kyiv-Mohyla Humanities Journal 8 (2021): 103-119

Published by: National University of Kyiv-Mohyla Academy

http://kmhj.ukma.edu.ua/ 


\title{
Playing Upon Biographical Myths: William Shakespeare and Lesia Ukrainka as Characters in Contemporary Drama
}

\author{
Natalia Vysotska \\ Kyiv National Linguistic Universirty, \\ Valentyna Fesenko Department of Theory and History of World Literature
}

\begin{abstract}
The article sets out to explore two plays by contemporary playwrights, one American (Don Nigro, Loves Labours Wonne), the other Ukrainian (Neda Nezhdana, And Still I will Betray You), focusing on William Shakespeare and Lesia Ukrainka, respectively, within the framework of "the author as character" subgenre of fictional (imaginative) biography. Accordingly, the article considers the correlation between the factual and the fictional as one of its foci of attention. Drawing upon a variety of theoretical approaches (Paul Franssen, Ton Hoenselaars, Ira Nadel, Aleid Fokkema, Michael MacKeon, Ina Shabert and others), the article summarizes the principal characteristics of "the author as character" subgenre and proceeds to discuss how they operate in the dramas under scrutiny. The analysis makes it abundantly clear that in Nigro's and Nezhdana's plays the balance between fact and fiction is definitively tipped in favor of the latter. By centering their (quasi) biographical plays on highly mythologized artists of national standing, both dramatists aimed at demythologizing these cult figures, inevitably placing them, however, within new mythical plots combining a Neo-Romantic vision of the artist as demiurge, with a Neo-Baroque as well as fin de siècle apology of death and a postmodern denial of one objective reality.
\end{abstract}

Key Words: biography, author as character, drama, William Shakespeare, Don Nigro, Lesia Ukrainka, Neda Nezhdana.

\section{(2)}

The current infatuation with biography on both ends of the author-reader literary playfield seems to be rooted in a paradox. On the one hand, the biographical genre, presupposing the discreteness and finiteness of any individual life unequivocally placed in a historical timeline, remains, apparently, within the scope of writings oriented towards "positive truths." On the other hand, postmodernism, with its repudiation of any such claims aims at dismantling both a Barthian "reality effect" and the alleged unity of any persona, be it historical or fictitious. It comes as no surprise, then, that in his introduction to a collection of essays dealing with the postmodern theory and practice of biography, its editor, William Epstein, poses a rhetorical question: “[And] isn't postmodernism an antihumanist, neoformalist movement that, among other things, seeks to demystify if not displace subjectivity, authority, intentionality, facthood, totality, coherence, and other conceptual practices crucial to the recognition of the biographical?"

$1 \quad$ William Epstein, "Contesting the Subject," in Contesting the Subject: Essays in the Postmodern Theory and Practice of Biography and Biographical Criticism, ed. William Epstein (West Lafayette, Indiana: Purdue University Press, 1991), 1. 
His answer is in the negative, though, and one can reasonably argue that it is the productive tension between two putatively mutually excluding approaches that lends the genre its charm and appeal for postmodernist writers, capitalizing on the multiple opportunities it provides for their favorite game of displacement and deconstruction.

Moreover, a host of biographies published in the final decades of the past century provided grounds for declaring ours the epoch of biography, not of postmodernism. ${ }^{2}$ Rather than engaging in direct confrontation with history (in this case, individual life stories), the strategies deployed by postmodern biographies are instrumental in subverting its validity from within by wantonly playing with facts - adding and omitting, rearranging and reinterpreting them - so as to demonstrate the illusory nature of any positive knowledge about an event or person. This article presents a study of two plays by contemporary authors - one American, the other Ukrainian - that can be broadly characterized as belonging to "the author as character" subgenre. The article aims at exploring the mechanisms of de- and re-mythologizing the figures of great national poets (William Shakespeare and Lesia Ukrainka) in the dramatic genre. Prior to analyzing the texts, a brief preliminary glance at the field might not be amiss.

\section{“The Author as Character” as a Subgenre of Fictional Biography}

The biographic tradition, of course, is one of the oldest in Western culture. At the same time, biography still causes endless theoretical controversy due to its duality as a generic formation amalgamating the factual and the fictitious. Trying to find his way in the labyrinth of varying opinions, John Keener concludes that the only established fact about biography is that after 400 years of critical attention nobody can say with certainty what it is. ${ }^{3}$ Being first a part of history, biography later evolved as a literary, rather than historical genre, with Plutarch's Parallel Lives functioning over centuries as the prime generic model. The Middle Ages substituted hagiography for biography, while the early modern period, with its newly awakened awareness of human individuality and keen interest in antiquity, saw the revival of the genre. The 18th century marked the turning point in its evolution, prioritizing positive knowledge as the basis for committing a life to paper (for example, The Life of Johnson by James Boswell, 1791). In the course of the 19th century, biographic conventions tended to merge with novelistic genre-forming features sufficiently developed by that time, since both had as their kernel the idea of autonomous subjectivity. In the early 20 th century biography was affected by the overall crisis of Eurocentric culture, with artists and thinkers either rejecting the genre altogether as unreliable and superfluous, or modifying it considerably. Sigmund Freud's, and later Eric Erikson's psychobiography,

Aleid Fokkema, "The Author: Postmodernism's Stock Character," in The Author as Character: Representing Historical Writers in Western Literature, eds. Paul Franssen and Ton Hoenselaars (Madison: Fairleigh Dickinson University Press, 1999), 42. 
as well as modernist "internalized biography" (Virginia Woolf) shifting the focus from external events to the central character's inner life, preempted postmodern experiments conducted within generic boundaries. In the last quarter of the zoth century, the quest for refurbishing the genre was often carried out within the broader framework of a movement towards the revision of historical fiction, given various names by different scholars - "postmodern historiographic metafiction," historical novel,"5 the "new historical novel," 6 etc. These definitions imply, among other things, the blurring of borders between fact and fiction inherent also in "biographical metafiction" (a term coined by well-known Canadian theorist of postmodernism, Linda Hutcheon). Actually, as biography theorist Jürgen Schlaeger aptly remarked, any human life as a sum of lived experiences is made up of both fact and fiction, and biography, as a "bastard child of history and fiction,"7 is best equipped for its literary transcription.

The above general remarks apply to different - and quite numerous - generic varieties of biography. As of today, a significant segment in biographical fiction is occupied by writers' life stories, widely referred to as "the author as character" (sub) genre. Paul Franssen and Ton Hoenselaars, editors of the influential volume The Author as Character: Representing Historical Writers in Western Literature, have every reason to claim that although "the author as character is not a recent phenomenon," "we certainly seem to be living in its heyday." Again, as is the case with biography as a whole, its popularity might appear paradoxical in an era marked by "the death of the author," heralded by famous post-structulalists Roland Barthes, Michel Foucault, and a legion of their lesser followers. According to Franssen and Hoenselaars, however,

the very postmodernism that proclaimed the death of the author and the demise of character delights in resurrecting historical authors as characters. This device offers a lively, economical way of not only raising but actually embodying such postmodern concerns as representation, the (im) possibility of historical knowledge, the share of the author in the genesis of a text, and intertextuality." Metafiction," in Postmodern Genres, ed. Marjorie Perloff (Norman: University of Oklahoma Press, 1989), 62.

$5 \quad$ Brian McHale, Postmodern Fiction (New York: Methuen, 1987), 90.

6 Seymour Menton, Latin America's New Historical Novel (Austin, TX: University of Texas Publishing House, 1993).

7 Jürgen Schlaeger, "Biography: Cult as Culture," in The Art of Literary Biography, ed. John Batchelor (Oxford: Clarendon Press, 1995), 66.

8 Paul Franssen and Ton Hoenselaars, “The Author as Character: Defining a Genre," in The Author as Character: Representing Historical Writers in Western Literature, eds. Paul Franssen and Ton Hoenselaars (Madison: Fairleigh Dickinson University Press, 1999), 18. Franssen and Hoenselaars, "The Author," 11. 
Dutch literary scholar Aleid Fokkema accounts for the seeming contradiction by stating that "what occurs in postmodernism is not the abolishment of the author but a relocation and reconsideration of his (its) function," ${ }^{10}$ with the emphasis laid not on the "death of the author," but on refiguring relations between a discursive and a real author.

Scholars situate the subgenre "at the crossroads between the historical novel, biography, and the Künstlerroman," comprising "conspicuously fictional forms, such as novels, short stories, plays, movies, dialogues, and dramatic monologues, featuring real-life authors, often, though not always, from the past." take the lead as the most common vehicles for "the author as character" stories, the genre is by no means restricted "to any specific form." It "was drama in particular, ... that formed an alternative, often popular outlet for representations of writers from the past." ${ }^{12}$ Professor Michael McKeon, who has written extensively on the theory of the novel, observed that "all biographies are in a sense also autobiographies, a truth that holds most of all for the writer's life, in which the story told is replicated at the level of form." ${ }^{13}$ Since both authors-characters under discussion (William Shakespeare and Lesia Ukrainka) excelled in drama, as well as in poetry, treating their life stories in dramatic form seems a natural choice.

The realization that "[T] $]$ he genre of the author as character is not scholarly biography, since it supplements or even replaces the documented facts of the authorcharacter's life with fictional speculation"14 appears to be of particular significance for the purposes of this article. According to American-Canadian critic and theorist Ira Nadel, any biography starts with a legend, a biographer's duty being correcting, denying, and revising it. In the course of the revision of facts, biography strives to demythologize its character, but this attempt ironically results in substituting new myths for old ones. ${ }^{15}$ This is true in the case at hand, too, since both Don Nigro and Neda Nezhdana choose as their subjects figures of national stature (not only in terms of their literary achievement, but also as potent agents of national identity formation), exceedingly mythologized in British and Ukrainian collective memory, respectively. In this context, it seems expedient to make use of the term "imaginative biography," suggested by prolific biographer Leon Edel ${ }^{16}$ and taken up by German English scholar, Ina Schabert, ${ }^{17}$ as both playwrights emphasize the supreme role played by imagination

$10 \quad$ Fokkema, “The Author," 39.

11 Franssen and Hoenselaars, "The Author," 18-19.

12 Franssen and Hoenselaars, “The Author," 16.

13 Michael McKeon, "Writer as Hero," in Contesting the Subject: Essays in the Postmodern Theory and Practice of Biography and Biographical Criticism, ed. William Epstein (Lafayette, Indiana: Purdue University Press, 1991), 38.

14 Franssen and Hoenselaars, “The Author," 19.

15 Ira Nadel, Biography: Fiction, Fact and Form (London: MacMillan, 1984), 178.

16 Leon Edel, Writing Lives: Principia Biographica (New York: Norton, 1984), 175.

17 Ina Schabert, In Quest of the Other Person: Fiction as Biography (Tübingen: Francke Verlag, 1990), 60. 
in producing their versions of canonical authors' lives. The next sections will take a closer look at the strategies and techniques they use to portray their celebrated subjects.

\section{De/Remythologizing Shakespeare in Don Nigro's Dramatic Fantasy}

Being conveniently located at the center of the Western canon, as Harold Bloom reminds us, William Shakespeare has long ago become one of its most viable cultural myths. In the 21st century, Shakespeare - not solely as a great artist, but also as an active "initiator of discursive practices," to use Foucault's formula, still remains a powerful presence exerting strong impact upon the manner in which Western habits of thought theorize the most fundamental categories of being. "In this sense, in setting the table for the ways in which we discuss, classify, and value substantive ideas," Shakespearean sholar Marjorie Garber argues that "Shakespeare has shaped not only the reception and reconception of his own (and other) artwork, but also the very possibility of social analysis and cultural conversation in the present day." ${ }^{18}$ Over time the "Shakespeare" brand does not diminish in socio-cultural value, but the modes of its exploitation are customized to suit the needs and tastes of each new generation. In the postmodern period, the Shakespearean "text" as a sum total of each and every line penned by him, the zillions of words written about him, his personal myth, and innumerable "ripples on the water" caused by his four-and-a-half hundred-year presence in global culture constitutes an inalienable part of the latter, both in its "high" and "low" varieties.

A considerable portion of the Shakespearean "text" is made up of his biographies, both scholarly and fictional. According to well-known Shakespearean critic Anne Barton, "[S]ince 1996, every year has seen the publication of at least one and sometimes several large-scale new attempts not only to chronicle the life of the glover's son from rural Warwickshire who became England's greatest poet and dramatist, but to reach out beyond the few stark and largely enigmatic facts to uncover his personality and private beliefs."19 She has in mind academic publications, but the stream of biographical fiction focusing on the Bard's life is no less impressive. In her analysis of postmodern literary works portraying Shakespeare, Alicia Williams asserts that "it is the presence and development of William Shakespeare as a character in modern fiction that has helped to bring about ... current enthrallment with the playwright." ${ }^{20}$

18 Marjorie Garber, Shakespeare and Modern Culture (New York: Pantheon Books, 2008), xxx.

19 Anne Barton, "The One and Only," New York Review of Books, 53.8, May 11, $2006,22$.

20 Alicia Williams, "The Portrayal of William Shakespeare in Modern Fiction: The Author-Character as a Sub-Genre of the Postmodern," accessed September 15, 2020, https://www.academia.edu/2548185/The_Portrayal_of_William_Shakespeare_in_ Modern_Fiction_The_Author-Character_as_a_Sub-Genre_of_the_Post-Modern. 
Don Nigro's dramatized “imaginative biography," Loves Labours Wonne (1981/1995), constructs his own image of the artist's ever Protean figure. Shakespearean allusions take a place of honor in the prolific American dramatist's body of plays. In addition to Loves Labours, they inform the travesty The Curate Shakespeare As You Like It (Being the Record of One Company's Attempt to Perform the Play by William Shakespeare) (1976/1986), as well as The Girlhood of Shakespeare's Heroines (1988/1995), and Boar's Head (2005). (The first figure indicates the date of the first production, the second - the year of publication.) My hypothesis is that Nigro's Shakespeareana has at its core the category of theatricality in its broadest meaning - from the stage per se to a human life and further to the Universe, modified in each play to serve its particular purpose.

Theatricality as a universal metaphor for life/world, introduced by Plato and Epictetus and running through European cultural history, is inseparably connected to the festive and the ludic, important factors in the 2oth century philosophy of culture (Johan Huizinga, Hans-Georg Gadamer and others). Don Nigro reiterates these ideas in his notes for the Curate Shakespeare: "Theatre itself becomes the central metaphor in Shakespeare's work and is as well in some respects the central metaphor of Western civilization." ${ }^{21}$ Under his pen "the theatre of life" acquires pronounced Existentialist features. His "decimated and bedraggled" company "look out into the darkness," with no assurance that "anybody is out there watching" (the existentialist motif of Godabandonment), and that "their desperate attempts to make a dead Englishman's old play come alive have any meaning or purpose separate from their own unreasonable desire to try." ${ }^{22}$ The failure seems imminent. The actors want to quit, "but their persistence begins eventually to approach a kind of bizarre heroism.

What began as torture and humiliation evolves gradually into a kind of triumph... Their situation is hopeless, their predicament defies explanation, they are ridiculous, but their struggle brings them a certain amount of dignity and a taste of some manner of brief salvation. They are, in short, just like us. ${ }^{23}$

Nigro also revitalizes one of the central topoi of Western culture, namely, the equation "God = demiurge = artist," as a leitmotif for most of his drama. In Michael McKeon's words, "the Renaissance doctrine of the artist as creator first broached the daring notion of a human spiritually imitative of the divine, but it remained for the Enlightenment to accept the challenge by propounding a doctrine of aesthetic creation

21 Don Nigro, The Curate Shakespeare As You Like It (Being the Record of One Company's Attempts to Perform the Play by William Shakespeare) (New York: Samuel French, 1986), 97 .

22 Nigro, The Curate, 97.

23 Nigro, The Curate, 98. 
that effectively replaced God's authority with that of the human author." ${ }^{24}$ This tendency appears to have reached a zenith in Romanticism, to be later carried on by Modernism. The identification of a creative artist with God/demiurge underlies Nigro's "Shakespearean" plays, with not only the Great Stratfordian, but the author himself sometimes entering the equation. This consideration has an immediate bearing on the play Loves Labours Wonne.

In addition to "the author as character," Loves' genre may be identified as a dramatic fantasy fashioned around the Bard's biography. Its deliberately archaized title sends us back both to Shakespeare's early comedy Love Labours Lost (the second half of 1590s), and its "mirror double" - the play Love Labours Wonne, dating back, presumably, to approximately the same period but, unfortunately, lost to posterity. It is, however, mentioned in a major period source, namely, Palladis Tamia, Wits Treasury (1598) by Shakespeare's contemporary Francis Meres, to whom we owe several precious mentions of Shakespeare. Nigro makes no attempt whatsoever to reconstruct the lost text; instead, he weaves a fabric of symbolic images around its creator's figure. In treating Shakespeare as a character in drama, Nigro has several illustrious predecessors, such as celebrated British playwrights George Bernard Shaw and Edward Bond, each using the famous author's figure to pursue political or aesthetic goals of their own. Nigro is no exception.

Contemplating theoretical complexities produced by fictional biographies, Philip Stevick suggests that one way of examining them is "to draw upon the commentary" of their authors. "Generally self-conscious about what they do, the writers of such fiction tend to be incisive and witty, profoundly interesting." ${ }^{25}$ This is certainly true of Don Nigro. In his notes the dramatist feels compelled to explain his position as a fictional biographer. He chastises the critics, asserting that "it is impossible to write a good play about Shakespeare" - in his opinion, they fail to "distinguish between mythological and discursive forms" embodied by art and history, respectively. ${ }^{26}$ He agrees that it would be, indeed, futile to try and write the definitive play on Shakespeare, since there is no such thing as a definitive play about anybody or anything. On the contrary, he sees his endeavor as "a moving tapestry of symbols, the tracing of an archetypal pattern which generates mythological, not discursive truths." ${ }^{27}$ Since he approaches Shakespeare as a playwright, not as a critic or historian, Nigro continues, the poet is for him a mythological figure, "as much as Richard III, Lady Macbeth and Falstaff must have been mythological figures to Shakespeare." ${ }^{28}$ Here the American playwright sees eye to eye with influential Canadian literary critic and theorist Northrop Frye, for whom biography cannot be but mythological since it transposes individual

\footnotetext{
24 McKeon, “Writer," 20.

25 Philip Stevick, "Review of In Quest of the Other Person: Fiction as Biography by Ina Schabert and Exile and the Writer: Exoteric and Esoteric Experiences by Bettina Knapp," MFS 37.4 (1991): 824.

26 Don Nigro, Loves Labours Wonne (New York: Samuel French, 1995), 102.

27 Nigro, Loves, 102.

28 Nigro, Loves, 102.
} 
effort into mythological experience. Biography moves from metonymy to metaphor, from individual life struggle to general conditions. In this manner biography moves from the domain of history into the domain of myth, ${ }^{29}$ making it contingent to the central archetype of death and resurrection. Shakespeare's potential as a mythological hero is further enhanced by his grandiose creative effort. It is his ultimate quest, "the quest to understand and to create out of one's struggle to understand" that "connects him upwards of the archetypal scale to another mythological creature/ hero - God of the Old Testament, and downwards on the scale to me, another creator and universe maker."30 Here we see at work the formula "artist = creator," or "playwright = demiurge," discussed above. Still, this premise in no way contradicts Nigro's determination to use as many historical facts as he can avail himself of.

Following a model much favored in modern fictional biography, Nigro does not conform to a chronological sequence of events. The non-linear architectonics of his play is devoid of a traditional plotline and consists of isolated, seemingly unrelated episodes from various periods in Shakespeare's life. They are to be unified in the audience's minds and come together not as an array of ordered biographical occurences, but as a spiritual biography of the artist. Despite the play's fragmented and loose structure, its scenes are firmly cemented by means of ingenious dramatic and theatrical techniques, such as the simultaneous presence on the stage of characters belonging to different chronotopes, "echoes" between lines uttered in consecutive episodes, blurred boundaries between scenes, polysemantic stage metaphors, etc. Although the content is based on ascertained facts from Shakespeare's life (his marriage to Ann Hathaway, the London circle of "university wits," theatrical hits and flops, etc.), the space constructed on the stage is virtual and phantasmagoric, where historical figures (queen Elizabeth, Christopher Marlowe, Robert Greene, Philip Henslowe, Richard Burbage, Edward Alleyn, and others) freely coexist and interact with semi-legendary ones (Dark Lady), as well as with literary characters and other creatures of Shakespeare's imagination. Their identities oscillate, transcending interpersonal boundaries and merging into a dream-like (or mythic) continuum - thus, the drowned Ophelia turns out to be the Dark Lady. Shakespeare himself declares this dramatic principle in the prologue: "I fled in grief and horror from the woods and fields of Stratford to the unreal city, this, and here I lived in fantasy, clothed myself in playhouse lies until the fashioned and the real became so hopelessly confused I can no longer separate them out." ${ }^{11}$ Thus, the traditional biographical dichotomy of "fact/fiction" is reconceptualized here as a leveled opposition between "reality" and "fantasy," so that the action unfolds in the oneiric mode of reminiscences, dreams, and visions.

The idea of universal theatricality is implemented in both dramatic and stage languages, rich in verbal and visual metaphors and symbols. The image of "trap," for

29 Northrop Frye, The Great Code: The Bible and Literature (Toronto: University of Toronto Press, 2006), 59.

$30 \quad$ Nigro, Loves, 104-05.

$31 \quad$ Nigro, Loves, 7. 
one, performs an important meaning-generating function. At the outset it is just part of a stage mechanism - a hole in the floor used for characters' appearance and disappearance. Later it acquires ambiguous erotic/thanatologic connotations of vagina/woman and grave/death, and, finally, stands for the physical world as a whole ready to "devour" a creative personality.

The play's rhetoric is marked by a combination of high poetry and extreme naturalism bordering on physiology (e.g. cannibalistic discourse, or Shakespeare's perception of London as a seat of death and decay: "stomach of hell," "dead animals, heaps of dung, butchers' leavings, bits of gut and rot in the streets, buckets of blood the barbers throw out the windows like bathwater"32). Semantic and stylistic contrasts are characteristic of Manneristic and (Neo)Baroque aesthetic paradigms practiced by the late Shakespeare and imitated by Nigro. The play is intertextual all the way through, with numerous explicit and implicit Shakespearean quotes, reminiscences, and allusions skillfully incorporated into its fabric. Puns contribute to the play's verbal allurement, and Nigro's craftsmanship in coining them is noteworthy (e.g. lines from the prologue: "Oh, for a muse on fire, Oh, for musing friar...," or the periphrasis of Richard III's famous exclamation, where instead of "a horse" he offers his kingdom for "a hearse").

Nigro's central "theatrical" concept is complemented by the confrontation, or rather, dialectics of the material and the spiritual - the two fundamental elements, dragging his Shakespeare in opposite directions. They are incarnated in Shakespeare's infernal ("chthonic") and sublime ("aerial") womenfolk - Ann, the Dark Lady, the poet's daughters Judith and Susanna, as well as his female characters. The transience and temporariness of everything material, doomed to death and decay, is opposed to the immortality of the creatures of the Spirit. In the play's finale, speaking on behalf of all the characters created by Shakespeare, Miranda consoles the lonely, sick, and desolate author: "You've got US, silly. You can lose your friends, your love, your children, but you can't lose us, we're in your head. The rest is borrowed. It's lovely, but it's borrowed. All flesh is borrowed. It's precious what you borrow, be good to it, and cherish it, but don't mistake what's borrowed for what's not. We're in your soul. Your soul's the stuff we're made on." ${ }^{33}$ Her speech contains allusions to the enlightened Lear on the heaths tearing off his clothes ("off, off you lendings!") and to Prospero's famous line from The Tempest ("We are such stuff as dreams are made on"). For the author, it is the interaction between these elements that predetermines theatre's "alchemy," where the product of a playwright's mind is turned into matter on stage, and then, "during the performance, theactors turn it back to mind, in the minds of the audience." 34 "The organic world is what has made us," Nigro concludes. "Art is what we make. We are a part of both, need both, fear both. Both are fragile. Both can turn on you at any moment. This is love." 35 
Therefore, the traditional myth of Shakespeare as a poet par excellence, inherited from the epoch of bardolatry, gets modulated by Nigro into a myth of an ambivalent and tortured creator torn apart, Orpheus-like, by his humanity and divinity, and finally swallowed by a trap, not unlike Don Juan in Mozart's opera, hinting at a demonic component of his self.

\section{Neda Nezhdana's Lesia Ukrainka: From the Iron Maid to a Flesh-and-Blood Woman}

Lesia Ukrainka (Larysa Petrivna Kosach-Kvitka, 1871-1913), the great national poet, who lived her brief life of toil at the turn of the zoth century, is the only woman in the canonical trio of Ukrainian literary "ancestors," including also Taras Shevchenko and Ivan Franko. Her pen name means “a Ukrainian woman.” This year's celebration of Lesia Ukrainka's 15oth anniversary could not but boost attention to her work and person, coupled with a revision of long-established myths about this appealing and complex literary figure.

Neda Nezhdana (Nadiia Leonidivna Miroshnychenko, b. 1971) is a contemporary Ukrainian poet, playwright, art critic, journalist, and interpreter, with her plays being produced in Ukraine, Russia, Poland, and the USA. Her pen name "Nezhdana" means "not waited for," "unexpected," and her drama, referred to in critical studies as belonging to the "new-new wave" in Ukrainian theatre, justifies the name to a certain extent. Turning to her one-acter I vse-taky ya tebe zradzhu (1998; And Still I Will Betray You), focusing on Lesia Ukrainka's life story, we can spot many typological similarities between the two "imaginative biographies." To begin with, Nezhdana's "dramatic improvisation," as the author defines its genre, also relies heavily on the concept of theatricality. Drawing, like Nigro, upon this universal cultural category, Nezhdana also pays tribute to an original Ukrainian form of entertainment - the vertep (traditional itinerary puppetry representing Christian mystery plots) dating back to the 17th century. In the play, sequences from Lesia Ukrainka's life story are inscribed in a parabolic framework with two stock characters, Harlequin (commedia dell'arte) and Pierrot (French pantomime) functioning as the heroine's symbolic escorts from birth to death. As a result, the piece acquires features of a European Medieval morality play, with God and the Devil fighting for a human soul, as well as its Ukrainian counterpart a vertep show loosely based on the Passion play. The two personages are fluid and mutable - having introduced themselves as "white angel" (or Good Spirit) and "black angel" (or Evil Spirit), ${ }^{36}$ they also refer to themselves as Lesia Ukrainka's "laughter" and "crying," further appearing as tricksters donning masks of beggars and flower vendors. They are narrators, too, and, in accordance with their original theatrical function of servants, act as communicators between "The Playwright" and the heroine. "The

36 Neda Nezhdana, "I vse-taky ya tebe zradzhu [And Still I Wll Betray You]," in Neda Nezhdana, Provokatsiia inshosti (Kyiv: Ukrainskyi pysmennyk, 2008), 13. 
Playwright," apparently analagous to a deity in his manipulation of Lesia Ukrainka's stage life, is an intraheterodiegetic dramatis persona commenting upon the action, mostly through Nietzschean quotations from Thus Spoke Zarathustra. The choice of philosophical background seems justified, considering the German philosopher's popularity in the fin de siécle European cultural climate, Ukrainian included, and Lesia Ukrainka's particular interest in his ideas.

The author emphasizes the playwright-as-God ambiguity, pointing out that his costume should betray traces of a "conjurer" and thus suggesting, in addition to his divinity, a demonic narrative mode. As a matter of fact, the notorious trio (the Playwright, Harlequin, and Pierrot) becomes highly reminiscent of Mikhail Bulgakov's supernatural characters in his Master and Margarita, which, as the archetypal artistas-subject novel in (post)Soviet literature, might have been one of the inspirations for Nezhdana. Her Playwright possesses features both of Bulgakov's (invisible) God and the all too visible diabolic Voland. The equation between Artist (playwright) and God, so prominent in Nigro's play, holds true for Nezhdana as well. In her case, it is enhanced by the fact that Lesia Ukrainka's poetry and drama lie largely in the realm of Modernist aesthetics, idolizing the creative person as unique, nearly superhuman/divine, and prophetic. Developing "the author as character" theme in an innovative postmodern key, the contemporary writer engages in a dialogue with her subject/predecessor about how an artist's life can be represented - now agreeing, now disagreeing with the previous epoch's assumptions and practices.

Unlike Nigro, who explicates his method metatextually, in accompanying writer's notes, Nezhdana incorporates its discussion into the text using her alter ego, the Playwright, as the medium. He explains that "today's plot is about love and betrayal, about the painful happiness of the loneliest of all - a person of genius. I'll write a play without pen or paper, here and now, a play about the sweet appeal of a talented and hapless woman. I did not strive for verisimilitude. Perceive everything as myth, legend, and parable." ${ }^{37}$ These words make it abundantly clear that Nezhdana's "imaginative biography," like Nigro's, is also driven by the desire to get to the archetypal (mythological, legendary) core of its author-character's life, hidden beneath the surface of mundane facts. Before getting back to the centrality of myth for Nezhdana's play, it is worthwhile pinpointing further resemblances to Nigro's Loves Labours Wonne.

Both plays are preoccupied with death. Ukrainian drama scholar Olena Bondareva states that "in Neda Nezhdana's play we can notice an intensive pedaling of the NeoBaroque concept of death as a background, a foundation upon which the heroine's life will transpire in a dotted line, as a spectacle, a moment, a flash." ${ }^{8}$ Further on, she offers a detailed discussion of the affinity between pathology and genius in 2oth century

37 Nezhdana, "I vse-taky," 13.

38 Olena Bondareva, Mifi drama u novitniomu literaturnomu konteksti: ponovlennia strukturnoho zviazku cherez zhanrove modeliuvannia [Myth and Drama in Current Literary Context: Restoring Structural Connection through Genre Modeling] (Kyiv: Chetverta khvylia, 2006), 217. 
psychiatry and cultural studies. In both Nigro's and Nezhdana's works thanatological motifs can be attributed to (Neo)Baroque tendencies in postmodern culture as one of their sources. But apart from this common denominator, they have different origins. For Nigro, it is, fist and foremost, Shakespeare's affiliation with Mannerist and Baroque aesthetics that legitimizes his biographer's "diving" into their ideational and imagery pool for inspiration. Besides, the overall gloomy atmosphere of Nigro's plays, only sporadically relieved, as in the Baroque proper, by comic interludes, reflects on the playwright's pessimistic world view and Existential angst. With Nezhdana, on the other hand, the omnipresence of death may be accounted for by at least three factors: first, the importance of the Baroque for Ukraine, where it constituted one of the most original and productive cultural periods; second, Lesia Ukrainka's rootedness in fin de siécle European intellectual soil, marked by (not infrequently) a pathological interest in the macabre, the decadent, and the dying; and, last but not least, Lesia Ukrainka's own terminal disease, bone tuberculosis, that left an indelible mark on her life and finally swept her away at the premature age of forty-two.

It was her physical sickliness combined with her (presumably) "iron will" and revolutionary attitudes that constituted the core of Lesia Ukrainka's pre-Soviet and Soviet myth (a fragile woman overcoming her physical ailment by the manly strength of her spirit), demolished, in part, in Nezhdana's play. Lesia Ukrainka's androgynous myth seems to have taken its origin from influential late 19th - early 2oth century Ukrainian literary figure Ivan Franko referring to her as both a "sickly weakling of a girl" and "the only man" in the Ukraine of her times. ${ }^{39}$ Literary critic Halyna Levchenko convincingly argues that the myth further developed along two main lines hagiographic and heroic, depending on the writer's ideological stance..$^{40}$ In Nezhdana's play, the affliction is still there, and very much so, but other components of a Socialist Realist treatment of the cult figure are gone. The playwright is by no means a pioneer in her project of demythologizing Lesia Ukrainka; such attempts have consistently been part of a broader project aimed at rewriting national (literary) history, following Ukraine's independence in 1991. In Lesia Ukrainka's case, they were undertaken by major Ukrainian scholars, such as Vira Aheieva, Solomiia Pavlychko, Nila Zborovska, Tamara Hundorova, writer Oksana Zabuzhko, and others, from a variety of perspectives. These included the urge to inscribe the Ukrainian poet into a European context; feminist interpretations of her life and work; shifting the focus to her national, rather than class liberation impulses; contesting the vision of Ukrainian culture as predominantly "rural" by accentuating Lesia Ukrainka's intellectuality and sophistication, etc. In her 2007 essayistic biography, Notre Dame d'Ukraine: Ukrainka in a Conflict of Mythologies, Oksana Zabuzhko, in a reviewer's words, tries “to bring

39 Ivan Franko, "Lesia Ukrainka," accessed September 15, 2020, http://ukrlit.org/faily/ avtor/franko_ivan_yakovych/franko-lesia_ukraiinka.pdf.

$40 \quad$ Halyna Levchenko, "Heroizm versus sviatist: do problemy mifolohizmu v literaturoznavchii retseptsii zhyttievoho i tvorchoho shliakhu Lesi Ukrainky [Heroism versus Sanctity: On Mythologism in the Literary-Critical Reception of Lesia Ukrainka's Life and Work]," Pytannia literaturoznavstva 87 (2013): 388. 
the aristocratic project back to Ukrainian culture through a paradoxical feministknightly myth." "41 Indeed, as the title suggests, the poet is presented as the "Holy Spirit's female knight," a "faithful priestess" of a "persecuted and repressed female deity who, owing to heresies, succeeded in making her way into the Western Christian canon under a name symmetrical to the Lord's name, - Notre Dame, 'Our Lady." 42 Tamara Hundorova, in her turn, considers Lesia Ukrainka's phenomenon in terms of an antiChristian "feminist communicative utopia," claiming that by granting a voice to women the poet incorporates female subjects into reality, culture, and history, "vindicating a shadow, an emptiness, and asserting the reality of human life lived 'here and now." 43

At first glance, Neda Nezhdana's project looks much more modest, limited to the poetess' private life, with her creative genius just suggested, hinted at by its material traces (pens, sheets, and bits of paper) and a few poems recited in the play. This strategy gave rise to critical reprimands to the effect that "the audience must believe in [Lesia Ukrainka's] genius not by force of the dramatic text, but by force of school textbooks." 44 It would seem, however, that the task of re-creating acts of Art on the stage is not only next to impossible, but in this case utterly unnecessary, since, thanks to the very same "school textbooks," the maxim of Lesia Ukrainka's genius gets embedded in the Ukrainian audience's collective mind since childhood. Nezhdana's central interest moves from the Poet to a (very talented) Woman who is featured as a martyr to her disease and gift. The latter is posited as a burden, "a cross," and, consequently, Lesia Ukrainka, portrayed as a loving and suffering woman rather than a poet-prophet or a revolutionary fighter, grows intoa Christ-like figuregoing through death and resurrection (Northrup Frye's central biographical archetype), as implied in the epilogue.

Nezhdana's play is both intimate, like a piece of chamber music, and allembracing in its allegorical sweep. On the one hand, only a couple of threads from Lesia Ukrainka's rich life are untwined; personages are limited in number, including, in addition to the stage trio and Lesia Ukrainka herself, three other characters, the three men who were "significant others" in Lesia Ukrainka's life. On the other hand, on the parabolic plane, it claims universal status as a statement about an Artist's mortal life and posthumous immortality. The action is free-flowing and continuous. The twelve scenes join seamlessly, framed by a prologue and an epilogue. "Zannies" introduce each episode, divulging pieces of biographical information. Quasi-mimetic scenes depicting (imaginary) episodes from Lesia Ukrainka's life in a naturalistic mode

$41 \quad$ Nila Zborovska, “Nasha pani' Lesia Ukrainka u tlumachenni Oksany Zabuzhko (Intelektualni paradoksy kulturnoho feminizmu) ['Our Lady' Lesia Ukrainka as Interpreted by Oksana Zabuzhko (Intellectual Paradoxes of Cultural Feminism)]," Slovo i chas 9 (2007): 69. d'Ukraine: Ukrainka in a Conflict of Mythologies] (Kyiv: Fakt, 2007), 6o9. Tamara Hundorova, ProYavlennia Slova. Dyskursiia rannioho ukrainskoho modernizmu. Postmoderna interpretatsia [The Emerging Word: The Discourse of Early Ukrainian Modernism. A Postmodern Interpretation] (Kyiv: Krytyka, 2009), 412-13. Valentyna Zabolotna, "Poikhaly! [Let It Roll!]," Ukrainskyi teatr 6 (2001): 5. 
alternate with overtly symbolic sequences. The resulting counterpoint lends to the whole play its illusory, unreal, oneiric quality (still another feature in common with Nigro). It is enhanced by Harlequin's and Pierrot's rhythmic/ritualistic incantations delivered before the beginning and after the termination of the action, which sound like magic spells.

The "realistic" episodes are rather static, their action being mostly verbal. Lesia Ukrainka is shown in her intercommunication with the three men she loved in various periods of her life: first, her family's tenant, Georgian student Nestor Gambarashvili, the object of her youthful unrequited crush; then, revolutionary Serhii Merzhynskyi, bound to Lesia Ukrainka by an entangled knot of friendship and affection; and finally, her husband-to-be, sedate and mild lawyer turned musicologist, Klyment Kvitka.

As to the symbolic scenes, they represent a soul's progress from one transcedental state (prior to birth) to another (after death). In the prologue the unnamed Girl, who will become Lesia Ukrainka in her earthly hypostasis, is on the verge of being born; the setting in not unlike that of the Land of the Unborn in Maurice Maeterlinck's allegorical fairy tale The Blue Bird, 1908 (indicative of the strong Symbolist influence on European turn-of-the-century drama). The Girl's admiration for what she sees "below" echoes Miranda's ecstatic exclamation “Oh, brave new world!” (William Shakespeare, The Tempest) and is, in a similar manner, dispelled by Harlequin telling her that "it is a God-forlorn, devastated land" inhabited by nameless shadows. ${ }^{45}$ She, however, is promised a name and a gift from God that will be "as heavy, as a cross" - the line introducing the theme of the artist's (soul's) journey through life as her via dolorosa.

As mentioned above, the text abounds in morbid and macabre details related to sickliness and death. First, the story of Lesia Ukrainka's contracting consumption (tuberculosis) is recounted in the form of her interrogation by two "spirits." Then, every scene that follows has imagery evoking pathological/thanatological associations. Recurrent references are made to Lesia Ukrainka's frailty and disability, suddenly manifesting themselves amidst gaiety and "normality," setting the tone for her demise. In an early episode, the ghost of death appears in the shape of a dagger presented to her by the Georgian, hinting, due to her kinetics specified in stage directions ("raises the dagger over herself"), at the possibility of the protagonist's suicide. The relations with Merzhynskyi are colored in melancholic and grim hues from the outset due to his suffering from the same disease, eventually resulting in his death onstage. As for Kvitka, nine years Lesia Ukrainka's junior, he was also consumptive, and in the play, he holds on to Lesia Ukrainka's love as his only chance for salvation and survival. (In real life, supposedly, it was her insistence on their moving to the Crimea that became crucial for his recovery - he outlived her by 40 years). The death motif underlying the "biographical" episodes is developed on a symbolic plane, too. The (dead) flower symbol plays an important role here: in an interlude, Harlequin and Pierrot appear as flower vendors foisting their merchandise upon Lesia Ukrainka; on closer inspection, however, all the flowers turn to be either withered or dry, that is, suitable either for 
discarding or for gravesites. The two characters advise Lesia Ukrainka that wherever she is going, she'll find herself in a graveyard, since all roads lead there. The episode ends in Lesia Ukrainka reciting her famous poem in prose, addressed to Merzhynskyi and beginning with the words "Your letters always smell of withered roses, oh my poor withered blossom..." The next scene brings her and the reader/viewer to the addressee's deathbed. Lesia Ukrainka's husband's family name - Kvitka - means "a flower," thus adding another overtone to the floristic image. The wedding sequence, during which he feels unwell, is far from festive and readily lends itself to a reading in terms of an Eros/Thanatos conjunction in Western culture. This is the last scene in the play, followed by an "otherworldly" epilogue (Lesia Ukrainka died six years after her marriage), in which she observes her own funeral and tombstone from above. Polemics with the overly "manly" cultural representation she received from posterity is felt in her response to the monument - "It's a kind of blockhead in armor, and not me." At the same time, her desperate longing for the indifferent public's attention, theatrically and socially, albeit in the form of stomping, tomato-hurling, or hissing, is expressed by a Shakespearean periphrasis: "A hoard of money for a catcall, a hoard of money!" 46

It would be fair to point out, though, that in spite of the play's rather depressive atmosphere, Lesia Ukrainka is portrayed not only as a "sick woman of genius," but also as erudite, witty, and sometimes frivolous. Therefore, in disavowing the image of the greatest Ukrainian national female poet as an "iron lady" of her time, Neda Nezhdana proposes in its stead her own myth of a talented woman prevented from being happy in her personal life by a poetic gift, metaphorized, in line with Susan Sontag's pronouncements, through her excruciating disease. In her 1978 essay Illness as Metaphor the renowned American writer, thinker, and political activist set out to demysticize grave human diseases of that time (particularly, tuberculosis and cancer) by deconstructing the metaphoric trail accompanying them throughout history. Speaking about the perception of TB in quotidian and high-cultural discourses, she focused on its romanticization in the 19th and early 20 th centuries, leading to its being associated with ethereal spirituality, refinement, and psychological complexity. Consequently, one of the popular clichés of the time "connected TB (or consumption) with creativity." ${ }^{47}$ This general belief, in its turn, gave rise to an image of a talented artist afflicted with this fatal disease that intensifies her/his creative impulse before (s)he finally succumbs to it. Reverberations of this piece of mythology can be traced in Nezhdana's play, too.

\section{Conclusion}

It can be argued, therefore, that in rethinking the "fact/fiction" balance in their "author as character" plays, contemporary dramatists gravitate towards the latter, following the

46 Nezhdana, "I vse-taky," 34.

47 Susan Sontag, Illness as Metaphor (New York: Farrar, Strauss, and Giroux, 1978), 32. Later (1989) the writer complemented her discussion of illness as metaphor with AIDS as a case study. 
prescripts of postmodern sensibility and poetics. Choosing as their biographical subjects persons of letters assigned crucial roles in shaping British/American and Ukrainian national identities, Nigro and Nezhdana are intent on removing the patina of time and idolatry from these cult figures. Their efforts are aimed at disentangling Shakespeare and Lesia Ukrainka from the mythical "plots" historically woven around them to serve political agendas of legitimating certain social and symbolic orders. In their attempts at humanizing the characters, however, the playwrights unavoidably place them within different, but no less mythical plots combining a Neo-Romantic vision of the Poet as demiurge, with a Neo-Baroque apology of death, and postmodern questioning of the existence of one objective reality. Nigro's "Shakespeare" and Nezhdana's "Lesia Ukrainka," very different from their textbook counterparts, are constructed to meet the challenges of a specific cultural period. In future, they are sure to be replaced by other versions of their great prototypes, as will be demanded by the times.

\section{Bibliography}

Barton, Anne. "The One and Only." New York Review of Books. May 11, 2006.

Bondareva, Olena. Mifi drama u novitniomu literaturnomu konteksti:ponovlennia strukturnoho zviazku cherez zhanrove modeliuvannia [Myth and Drama in Current Literary Context: Restoring Structural Connection through Genre Modeling]. Kyiv: Chetverta khvylia, 2006.

Edel, Leon. Writing Lives: Principia Biographica. New York: Norton, 1984.

Epstein, William. "Contesting the Subject." In Contesting the Subject: Essays in the Postmodern Theory and Practice of Biography and Biographical Criticism, edited by William Epstein, 1-8. West Lafayette, Indiana: Purdue University Press, 1991.

Fokkema, Aleid "The Author: Postmodernism's Stock Character". In The Author as Character: Representing Historical Writers in Western Literature, edited by Paul Franssen and Ton Hoenselaars, 39-51. Madison: Fairleigh Dickinson University Press, 1999.

Franko, Ivan. "Lesia Ukrainka." Accessed September 15, 2020. http://ukrlit.org/faily/avtor/ franko_ivan_yakovych/franko-lesia_ukraiinka.pdf.

Franssen, Paul, and Ton Hoenselaars. "The Author as Character: Defining a Genre." In The Author as Character: Representing Historical Writers in Western Literature, edited by Paul Franssen and Ton Hounselaars, 11-35. Madison: Fairleigh Dickinson University Press, 1999.

Frye, Northrop. The Great Code: The Bible and Literature. Toronto: University of Toronto Press, 2006.

Garber, Marjorie. Shakespeare and Modern Culture. New York: Pantheon Books, 2008.

Hundorova, Tamara. ProYavlennia Slova. Dyskursiia rannioho ukrainskoho modernizmu. Postmoderna interpretatsia [The Emerging Word: The Discourse of Early Ukrainian Modernism. A Postmodern Interpretation]. Kyiv: Krytyka, 2009.

Hutcheon, Linda. "The Pastime of Past Time: Fiction, History, Historiographic Metafiction." In Postmodern Genres, edited by Marjorie Perloff, 54-74. Norman: University of Oklahoma Press, 1989.

Keener, John F. Biography and the Postmodern Historical Novel. Lewiston: The Edwin Mellen Press, 2001. 
Levchenko, Halyna. "Heroizm versus sviatist: do problemy mifolohizmu v literaturoznavchii retseptsii zhyttievoho i tvorchoho shliakhu Lesi Ukrainky [Heroism versus Sanctity: On Mythologism in the Literary-Critical Reception of Lesia Ukrainka's Life and Work]." Pytannia literaturoznavstva 87 (2013): 381-93.

McHale, Brian. Postmodern Fiction. New York: Methuen, 1987.

McKeon, Michael. "Writer as Hero." In Contesting the Subject: Essays in the Postmodern Theory and Practice of Biography and Biographical Criticism, edited by William Epstein, 17-41. Lafayette, Indiana: Purdue University Press, 1991.

Menton, Seymour. Latin America's New Historical Novel. Austin, TX: University of Texas Publishing House, 1993.

Nadel, Ira Bruce. Biography: Fiction, Fact and Form. London: MacMillan, 1984.

Nezhdana, Neda. "I vse-taky ya tebe zradzhu [And Still I will Betray You].” In Neda Nezhdana, Provokatsiia inshosti, 9-34. Kyiv: Ukrainskyi pysmennyk, 2008.

Nigro, Don. The Curate Shakespeare As You Like It (Being the Record of One Company's Attempts to Perform the Play by William Shakespeare). New York: Samuel French, 1986.

Nigro, Don. Loves Labours Wonne. New York: Samuel French, 1995.

Schabert, Ina. In Quest of the Other Person: Fiction as Biography. Tübingen: Francke Verlag, 1990.

Schlaeger, Jürgen. "Biography: Cult as Culture." In The Art of Literary Biography, edited by John Batchelor, 54-70. Oxford: Clarendon Press, 1995.

Sontag, Susan. Illness as Metaphor. New York: Farrar, Strauss, and Giroux, 1978.

Stevick, Philip. "Review of In Quest of the Other Person: Fiction as Biography by Ina Schabert and Exile and the Writer: Exoteric and Esoteric Experiences by Bettina Knapp." MFS 37.4 (1991): 824 .

Williams, Alicia. "The Portrayal of William Shakespeare in Modern Fiction: The AuthorCharacter as a Sub-Genre of the Postmodern." Accessed September 15, 2020. https:// www.academia.edu/2548185/The_Portrayal_of_William_Shakespeare_in_Modern_ Fiction_The_Author-Character_as_a_Sub-Genre_of_the_Post-Modern.

Zabolotna, Valentyna. "Poikhaly! [Let It Roll!]." Ukrainskyi teatr 6 (2001): 4-6.

Zabuzhko, Oksana. Notre Dame d'Ukraine: Ukrainka v konflikti mifolohii [Notre Dame d'Ukraine: Ukrainka in a Conflict of Mythologies]. Kyiv: Fakt, 2007.

Zborovska, Nila. “'Nasha pani' Lesia Ukrainka u tlumachenni Oksany Zabuzhko (Intelektualni paradoksy kulturnoho feminizmu) ['Our Lady' Lesia Ukrainka as Interpreted by Oksana Zabuzhko (Intellectual Paradoxes of Cultural Feminism)]." Slovo i chas 9 (2007): 69-73.

\section{(2)}

Natalia Vysotska holds a DSc degree in philology (literary studies) from the Taras Shevchenko Institute of Literature, National Academy of Sciences, Ukraine (1998). She is a full professor at the Department of Theory and History of World Literature at Kyiv National Linguistic University. In 1995 she was a Fulbright Fellow at the University of Mississippi. In 2002 she was a scholar-in-residence at the Kennan Institute of the Woodrow Wilson International Center for Scholars. Her research interests include multi/transcultural studies, ethnic literatures in the US, theater and drama, Post-Humanism, and geocriticism. 